\title{
DAMPAK HUBUNGAN INDUSTRIAL YANG BERSIFAT KAPITALISTIK TERHADAP HARMONISASI HUBUNGAN INDUSTRIAL PENGUSAHA DENGAN PEKERJA (Studi Kasus di PT Fiscous South Pacifik Kabupaten Purwakarta)
}

\author{
H. Gunarto \\ Fakultas Hukum Universitas Islam Sultan Agung Semarang \\ E-mail: gunartowr2@yahoo.com
}

\begin{abstract}
The implementation of the concept on freedom of rights for association of trade union is facing the phenomenon of liberal capitalistic global economic trends characterized by conflicting industrial relations. The problems in this research, What are the impacts of the implementation of the concept on freedom for association in trade unions to industrial relations which is capitalistic to the workers' welfare?. To answer these three problems, the writer used qualitative analysis with constructivism paradigm. This study draws some conclusions as follows, the implementation of the concept on freedom for association in trade unions, which is capitalistic, affects the following: (1) the high rates on labor strike, (2) the increasing number of disputes on industrial relations between the entrepreneurs and the workers.
\end{abstract}

Keywords: impact, industrial relations, capitalism

\begin{abstract}
Abstrak
Pelaksanaan konsep kebebasan berserikat melalui serikat pekerja dihadapkan pada fenomena kecenderungan ekonomi global yang liberal kapitalistik yang antara lain ditandai dengan hubungan industrial yang bersifat konflik. Permasalahan yang diajukan yaitu: Bagaimana dampak pelaksanaan konsep kebebasan berserikat melalui serikat pekerja pada hubungan industrial yang bersifat kapitalistik terhadap kesejahteraan pekerja?, Untuk menjawab permasalahan tersebut digunakan tradisi kualitatif dengan paradigma konstruktivisme. Studi ini menyimpulkan pelaksanaan konsep kebebasan berserikat melalui serikat pekerja yang bersifat kapitalistik terbukti berdampak pada: (1) tingginya angka mogok kerja, (2) banyaknya perselisihan hubungan industrial antara pengusaha dengan pekerja.
\end{abstract}

Kata kunci: dampak, hubungan industrial, kapitalisme

\section{Pendahuluan}

Pembahasan mengenai dampak hubungan industrial yang bersifat kapitalistik di Indonesia di era reformasi ini menjadi sangat penting, mengingat hubungan industrial di Indonesia tidak mampu menciptakan hubungan industrial yang harmonis. Beberapa indikator yang menunjukkan tidak harmonisnya hubungan industrial tersebut antara lain ditandai dengan masih banyaknya peristiwa mogok kerja yang dilakukan oleh pekerja sehingga berakibat pada turunnya produktifitas perusahaan, banyaknya perselisihan hubungan industrial, adanya perusahaan yang melakukan relokasi usahanya ke negara lain, bahkan tidak sedikit perusahaan yang menutup usahanya karena tidak baiknya hubungan industrial antara pengusaha dengan pekerjanya.

Memang sudah ada sistem hubungan industrial Pancasila yang pada zaman Orde Baru mampu menciptakan industrial peace yang semu, karena Pemerintah Orde Baru mampu melakukan pemaksaan pada pekerja dan pengusaha untuk melarang mogok kerja maupun penutupan perusahaan oleh pengusaha, tetapi harmonisasi hubungan industrial antara pengusaha dan pekerja yang ideal belum terjadi. Idealnya hubungan industrial di Indonesia mam- 
pu menciptakan industrial peace yang tidak semu, serta bagi pemerintah Indonesia akan mengurangi tingginya angka pengangguran, terciptanya lapangan kerja yang semakin luas, meningkatnya produktivitas perusahaan, meningkatnya kesejahteraan pekerja, bahkan mampu meningkatkan pertumbuhan ekonomi negara Indonesia yang tinggi di atas 6 persen.

Beberapa fakta fisik yang menunjukan pelaksanaan hubungan industrial di Indonesia berjalan tidak harmonis, berupa besarnya jumlah angka pemogokan kerja mulai tahun 2003 sampai dengan tahun 2008, yaitu sebagai berikut: tahun 2003 sejumlah 248 pemogokan, tahun 2004 sebanyak 356, tahun 2005 sebanyak 27, tahun 2006 sebanyak 127, tahun 2007 sebanyak 275 dan tahun 2008 sebanyak 79 mogok kerja. ${ }^{1}$ Fakta hukum menunjukaan bahwa hubungan industrial di Indonesia tidak mampu menciptakan harmonisnya hubungan industrial antara pengusaha dan pekerja dapat dilihat juga dari semakin meningkatnya jumlah perselisihan hubungan industrial yang diajukan Banding ke PTUN mulai tahun 2002 sampai tahun 2007, yaitu untuk tahun 2002 sebanyak 29 perkara, tahun 2003 sebanyak 42 perkara, tahun 2004 sebanyak 97 perkara, tahun 2005 sebanyak 157 perkara, tahun 2006 sebanyak 201 perkara, dan tahun 2007 sebanyak 262 perkara yang dimintakan upaya hukum ke Pengadilan Tinggi Tata Usaha Negara. ${ }^{2}$

Fakta sosial juga menunjukan pelaksanaan hubungan industrial yang tidak harmonis, dapat dilihat juga dari sangat tingginya angka Pemutusan Hubungan Kerja (PHK) pada tahun 2006 sebanyak 72.264 pekerja yang di PHK dan pada tahun 2007 sebanayak 28.317 pekerja yang kena PHK. ${ }^{3}$ Pengaturan hubungan industrial di Indonesia yang tidak dapat mewujudkan hubungan industrial yang harmonis tersebut

Laporan Dirjend Pembinaan dan Pengawasan Depnaker 2003-2008.

Laporan Tahunan Panitera P4 Pusat dari tahun 2002 2007. Bandingkan fakta ini dengan tulisan Catharina Dewi Wulansari, "Dimensi Baru Peran Pemerintah dalam Mengatasi Masalah Ketenagakerjaan Melalui Pembangunan Hukum Di Indonesia", Jurnal Hukum Pro Justitia, Vol. 24 No. 3 Juli 2006, FH Unpar Bandung, hlm. 227237.

3 Sumber: Ditjen PHI \& Jamsostek, Depnakertrans, Desember 2007. mendasarkan pada kosmologi barat yang dijiwai oleh nilai-nilai kapitalisme barat yang bersifat individual dan kapitalistik, yang sangat berbeda dengan kosmologi Bangsa Indonesia yang bersifat spiritual, kebersamaan dan harmonis .

Satjipto Rahardjo ${ }^{4}$ menyatakan bahwa hukum suatu bangsa mempunyai dan bertolak dari premis dasar, yaitu pandangan tentang manusia dan masyarakatnya, yang disebut dengan kosmologi hukum dari bangsa yang bersangkutan. Berdasarkan pendapat di atas dapat dikatakan bahwa hukum modern yang dipakai di dunia juga memiliki kosmologinya sendiri, maka dari sudut pandang tersebut hukum modern sebenarnya tidak netral. Hukum modern yang selama berabad-abad dikembangkan di Barat atau Eropa memiliki kosmologi yang diseleraskan dengan kondisi sosial politik masyarakat Barat atau Eropa yang bersifat individualistik, dan kapitalis.

Pada waktu hukum modern menyebar ke berbagai penjuru dunia, maka hukum modern masuk juga ke bangsa-bangsa di dunia yang memiliki basis kultural yang berbeda dengan Barat. Bangsa Indonesia memiliki basis kultural atau kosmologi sendiri yang berbeda dengan kosmologi negara-negara Barat, yaitu bersifat kolektif (tidak individual), keserasian-keseimbangan (harmoni), musyawarah dan menjunjung tinggi nilai-nilai spiritualitas. Kosmologi Bangsa Indonesia yang demikian terumuskan ke dalam Pancasila yang merupakan moral positif Bangsa Indonesia atau dapat dikatakan bahwa Pancasila merupakan basis kultural atau kosmologi hukum Indonesia yang dapat dilihat dari nilai-nilai yang terkadung dari kelima sila Pancasila.

Sila Pertama merupakan landasan spiritualitas dalam hubungan industrial di Indonesia, sila kedua merupakan landasan kemanusiaan dalam hubungan industrial di Indonesia, sila ketiga merupakan dasar kesatuan pengusaha, pekerja dan pemerintah dalam hubungan industrial di Indonesia, sila keempat merupakan landasan demokrasi dalam hubungan industrial di Indonesia, dan sila kelima merupakan landasan

\footnotetext{
4 Satjipto Rahardjo, Cara Bangsa Berhukum, Kompas, Senin 8 November 1993, hlm. 4.
} 
perwujudan keadilan sosial dalam hubungan industrial di Indonesia. Dalam hubungan industrial pekerja diberi hak untuk berserikat bagi pekerja, yang merupakan hak dasar yang dilindungi dan dijamin secara konstitusional sebagaimana yang tertuang di dalam UUD Pasal $28 \mathrm{E}$ ayat 3. Menurut Undang-Undang Dasar tersebut, pekerja harus diberi kesempatan seluasluasnya untuk mendirikan dan menjadi anggota serikat pekerja. Pendirian serikat pekerja mempunyai beberapa fungsi, yaitu: fungsi penyampaian aspirasi pekerja, fungsi kemitraan dengan pengusaha, fungsi kesejahteraan bagi pekerja, dan fungsi perlindungan bagi pekerja serta fungsi pengembangan bagi pekerja (Pasal 4 UU No. 21 Tahun 2000 tentang Serikat Pekerja/Serikat Buruh). Dalam menggunakan fungsifungsi tersebut, pekerja dituntut bertanggung jawab untuk menjaga kepentingan yang lebih luas yaitu kepentingan umum atau kepentingan bangsa dan negara. Oleh karena itu pembentukan serikat pekerja dilaksanakan dalam kerangka hubungan industrial yang harmonis dan dibatasi oleh kepentingan umum. Anggota serikat pekerja harus memiliki rasa tanggung jawab atas keberlangsungan perusahaan. Sebaliknya, pengusaha harus memperlakukan pekerja sebagai mitra sesuai dengan harkat dan martabat kemanusiaannya secara adil. ${ }^{5}$ Tetapi kenyataannya kehadiran serikat pekerja masih berbeda dengan apa yang dicitakan dalam pasal tujuan dibuatnya UU No. 21 Tahun 2000 tentang Serikat Pekerja.

\section{Permasalahan}

Berdasarkan uraian di atas permasalahan dalam makalah ini adalah bagaimana dampak hubungan industrial yang berbasis kapitalistik terhadap harmonisasi hubungan industrial pengusaha dan pekerja. Untuk menciptakan konsep hubungan industrial di Indonesia, yang mampu menciptakan industrial peace perlu digali nilai-nilai luhur bangsa Indonesia yang ada dalam Pancasila khususnya nilai keadilan.

\footnotetext{
5 Lihat mengenai profesionalisme pekerja dan pengusaha dalam Paulus Sukapto, "Penerapan Model Spencer \& Spencer dalam Penempatan Karyawan Secara Profesional", Jurnal Hukum Pro Justitia Tahun XX No. 1 Januari 2003 FH Unpar Bandung, hlm. 37-50
}

\section{Metode Penelitian}

Penelitian ini menggunakan paradigma konstruktivisme (constructivism). Paradigma merupakan seperangkat kepercayaan atau keyakinan dasar yang menuntun seseorang dalam bertindak pada kehidupan sehari-hari maupun dalam penelitian ilmiah. ${ }^{6}$ Penelitian yang di pakai menggunakan tradisi penelitian kualitatif dengan operasionalisasi penelitian yang berparadigma alamiah (naturalistic paradigm) ${ }^{7}$, karena dengan menggunakan metode penelitian kualitatif diharapkan akan ditemukan maknamakna tersembunyi di balik objek yang diteliti. ${ }^{8}$ Pendekatan yang dipakai adalah sociolegal approach. $^{9}$ Dalam konteks ini, institusi hukum tidak dipahami sebagai entitas normatif yang esoterik, akan tetapi justru dilihat sebagai bagian dari totalitas sistem sosial yang berada dalam keadaan kait-mengkait dengan variabel sosial lainnya. Dengan demikian, yang ditekankan di sini adalah membuat deskripsi tentang realitas sosial dan hukum, serta berusaha memahami dan menjelaskan logika keterhubungan logis antara keduanya. ${ }^{10}$

Social Seting penelitian untuk penelitian ini dilakukan pada pekerja tetap yang menjadi anggota serikat pekerja di dalam perusahaan, PT. Fiscous South Pacifik di Kabupaten Purwakarta, alasan penelitian disertasi dilakukan di PT. Fiscous South Pacifik di Kabupaten Pur-

6 Agus Salim, 2001, Teori dan Paradigma Penelitian Sosial (dari Denzin Guba dan Penerapannya), Yogyakarta: PT. Tiara Wacana, hlm. 33.

7 Lihat dalam Suteki, Rekonstruksi HMN Atas Sumber Daya Air (Studi Kasus Privatisasi Air), Disertasi, PDIH UNDIP, Semarang, 2008, yang menyatakan bahwa penelitian kualitatif mempunyai literasi empat unsur, yaitu: (I) Pengambilan/penentuan sampel secara purposive; (2) Analisis induktif-, (3) Grounded Theory, (4) Desain sementara akan berubah sesuai konteksnya. Bandingkan, Noeng Muhadjir, 2002, Metodologi Penelitian Kualitatif, Yogyakarta: Penerbit Rake Sarasin, hlm. 165-168.

8 S. Nasution, 1996, Metode Penelitian Naturalistik Kualitatif, Bandung: Tarsito, hlm 18

9 Zamroni menjelaskan bahwa model pendekatan semacam ini dikenal dalam beragam istilah sesuai disiplin ilmunya. Field research untuk studi sosiologi, naturalistic untuk studi-studi di bidang pendidikan, ethnograpic untuk studi anthropologi, dan socio legal research bagi disiplin ilmu hukum. Zamroni, 1992, Pengantar Teori Sosial, hlm. 80-81

10 Wahjah Al-Zailiy, al-Wasid fi Ushlulfiqhi al-Islami, Bairut: Darul Kitab, 1397-1398 H/ 1977-1978 M, hlm. 359. 
wakarta karena di Kab. Purwakarta mencerminkan situasi kosmologi Indonesia, sebagai kota penyangga Jakarta nilai-nilai individual dan kolektif tercermin di basis sosial perusahaan tersebut. Di PT. Fiscous South Pacifik di Kabupaten Purwakarta juga terdapat dua serikat pekerja dalam satu perusahaan (sebagaimana spirit UU No. 21 Tahun 2000 tentang Serikat Pekerja/Serikat Buruh), yaitu SPSI (Serikat Pekerja Seluruh Indonesia) dan PPMI (Persaudaraan Pekerja Muslim Indonesia).

Analisa data digunakan teknik analisis data tipe Strauss dan. J Corbin ${ }^{11}$, yaitu dengan menganalisis data sejak peneliti berada di lapangan (field), oleh karena itu selama penelitian, peneliti menggunakan analisis interaktif dengan membuat fieldnote yang terdiri atas deskripsi dan refleksi data. ${ }^{12}$ Selanjutnya peneliti akan melakukan klasifikasi data melalui proses indexing, shorting, grouping, dan filtering. Setelah data dari hasil penelitian di-anggap valid dan reliable, langkah selanjutnya adalah menganalisis secara induktif kualitatif untuk menjawab problematika yang menjadi fokus studi penelitian ini. Langkah-langkah teknik analisis data penelitian ini mengikuti model interaktif analisis data seperti yang dikemukakan oleh Mattew B.Miles and A. Michael Huber$\operatorname{man}^{13}$, yang bergerak dalam tiga siklus kegiatan: yaitu reduksi data, penyajian data, dan penarikan simpulan.

\section{Pembahasan}

Dampak Pelaksanaan Hubungan Industrial yang Berbasis Kapitalistik (Tingginya Jumlah Mogok Kerja dalam Hubungan Industrial)

Konsep hubungan industrial kapitalistik yang lebih berpihak kepada pengusaha, dengan ciri negara tidak boleh campur tangan dalam hubungan industrial, berakibat angka pemogokan tinggi. Walaupun mogok kerja adalah senjata pekerja yang semu dalam menciptakan kese-

11 Lihat A. Strauss and J Corbin, Busir, 1990, Qualitative Research; Grounded Theory Procedure and Techniques, London: Sage Publication, hlm 19.

12 Lihat HB Sutopo, 1990, Metodologi Penelitian Kualitatif Bagian II, Surakarta: Universitas Negeri Sebelas Maret Press, hlm 11.

13 Lihat, Mattew B. Milles and A. Michael Huberman, 1992, Analisis Data Kualitatif, Jakarta: UI Press, hlm 57. jahteraan pekerja karena akibat mogok seringkali berakibat penderitaan lahir batin bagi pekerja, sebagai akibat setelah mogok kerja pekerja di PHK oleh pengusaha.

Serikat pekerja PPMI PT South Pacific menggunakan mogok kerja sebagai jalan terakhir apabila perundingan dan negosiasi dengan pengusaha mengalami jalan buntu, khususnya dalam prosen pembuatan perjanjian kerja bersama (PKB) yang mengatur syarat-syarat kerja, pengupahan dan kesejahteraan pekerja ${ }^{14}$. $\mathrm{Di}$ PT. Fiscous South Pacific mogok kerja yang melibatkan sebagian besar pekerja dan menimbulkan proses produksi berhenti selama tiga hari berturut-turut pernah terjadi pada bulan Desember 2008 dengan tuntutan hak normatif pekerja berupa permintaan dana pensiun bagi pekerja, yang akhirnya dengan perantaraan pegawai pemerantaraan dari Depnaker Kabupaten Purwakarta dipenuhi oleh pengusaha. Pada tahun berikutnya sudah tidak ada lagi mogok kerja di perusahaan PT Fiscous South Pacific.

Setiap Hari Buruh yang jatuh pada tanggal 1 Mei, serikat pekerja PPMI Cabang Kabupaten Purwakarta menggunakannya untuk momentum refleksi kesejahteraan pekerja dan sosialisasi peraturan perundangan yang baru di bidang ketenagakerjaan, yang dihadiri perwakilan pengurus PPMI di perusahaan-perusahaan di Kabupaten Purwakarta. Kebijakan organisasi PPMI pusat tidak boleh menggunakan peringatan Hari Buruh tanggal 1 Mei untuk kegiatan mogok kerja karena budaya mogok kerja di PT FSP belum mencerminkan etika yang baik, apalagi untuk menjaga hubungan industrial yang harmonis, dan kebijakan ini dipatuhi oleh jajar-an pengurus PPMI kabupaten Purwakarta ${ }^{15}$.

Gerakan pekerja di Indonesia sejak awal kemerdekaan hingga saat ini diwarnai oleh gelombang pemogokan ${ }^{16}$ yang dapat dikatakan hampir tidak pernah reda. Perselisihan hubung-

\footnotetext{
14 Wawancara dengan Wahyudi, tanggal 13 Januari 2010

15 Suripto, Ibid, tanggal 20 Januari 2010.

16 Misalnya dalam kurun waktu sejak tahun 2000 sampai dengan April 2005, pemogokan yang terjadi di Indonesia berjumlah 3.400 kali, melibatkan 800.352 pekerja. Data ini diolah dari Laporan Tahunan tentang Perkembangan Kasus Pemogokan yang dikeluarkan oleh Direktur Jenderal Binawas Departemen tenaga Kerja Republik Indonesia dari tahun 2000 s/d April 2005.
} 
an industrial yang diikuti suatu pemogokan merupakan fenomena yang tak mudah untuk dihindarkan oleh para pihak yang terikat dalam suatu hubungan kerja. Keadaan semacam ini juga dialami di berbagai belahan dunia yang hubungan industrialnya bersifat kapitalistik, misalnya di Amerika Serikat ${ }^{17}$, Eropa Barat ${ }^{18}$ seperti Inggris, Perancis, Jerman, Belanda, dan sebagainya, serta di negara-negara Asia seperti di Jepang ${ }^{19}$ dan di China. ${ }^{20}$ Terjadinya pemogokan-pemogokan tersebut di atas sulit untuk dihindarkan, karena bagi pekerja mogok merupakan hak fundamental yang inherent dengan hak kaum pekerja untuk berunding. Hal ini tercermin dari alasan-alasan terjadinya mogok kerja di berbagai negara.

Pemogokan-pemogokan yang terjadi di Indonesia sedikitnya disebabkan oleh berbagai faktor Antara lain berkaitan dengan tuntutan kebebasan berserikat; tuntutan kenaikan tingkat upah; tuntutan agar diberikan Tunjangan Hari Raya; tuntutan pelaksanaan ketentuan-ketentuan hukum perburuhan (tuntutan normatif) yang berkaitan dengan pelaksanaan jaminan Sosial Tenaga Kerja, jam kerja, hak cuti (menstruasi), kontrak kerja serta syarat-syarat kerja lainnya; ${ }^{21}$ dan tuntutan yang berlatar belakang

17 Pemogokan-pemogokan Umum di Amerika Serikat yang tercatat sangat signifikan antara lain adalah: Great Upheaval Strike 1877, Textiel Strike 1936, Railroad Strike 1946, dan Postal Strike 1970. Lihat Jeremy Brecher, 1997, Strike, Cambridge: South End Press Classics, hlm. 295

18 Di seluruh negara Eropa Barat pada akhir tahun 1970-an telah terjadi pemogokan sebanyak 14.754 kali yang melibatkan 21 juta buruh. Lihat Maximos Aligisakis, "Labour Dispute in Western Europe: Typology and Tendencies," International Labour Review, 136; (Spring 1997, No. 1) hlm. 75.

19 Di Jepang pada tahun 1976 tercatat 3.26 juta jam kerja telah hilang akibat pemogokan. Frekuensi pemogokan di Jepang ini rendah karena hubungan industrial di Jepang menekankan pada "harmony model," dimana tindakan mogok dianggap sebagai "warning" bagi pengusaha untuk kembali ke meja perundingan. Lihat: William B. Gould, "Labor Law in Japan and the United States: A Comparative Perspective," Industrial Relations Law Journal, 6, (1984, No. l ) hlm. 16.

20 Di Cina misalnya pada tahun 1956-1957 telah terjadi 10.000 kali pemogokan I diet: Xiaobo Lu, and Elizabeth J. Perry, 1997, DANW'El: The Changing Chinese Workplace in Historical and Comparative Perspective, New York and London: An East Idle Book, hlm. 48-51.

21 Lihat mengenai kontrak kerja ini pada Yohanes Suhardin, "Eksistensi Outsourcing dan Kerja Kontrak dari Perspektif Hak Asasi Manusia", Jurnal Hukum Pro politik. Faktor-faktor yang menyebabkan terjadinya pemogokan tersebut di atas dapat diuraikan sebagai berikut. Pertama, tingkat upah pekerja yang rata-rata masih rendah serta syarat-syarat kerja yang dirasakan oleh kaum pekerja kurang memadai, ${ }^{22}$ telah memicu terjadinya pemogokan-pemogokan. Sebagian besar dari pemogokan-pemogokan yang terjadi dilatarbelakangi tuntutan kenaikan upah. ${ }^{23}$ Pada tahun 1950 di Bandung, sekitar 50.700 pekerja yang awal mulanya diprakarsai oleh SARBUPRI (Serikat Buruh Perkebunan Republik Indonesia) melakukan aksi pemogokan menuntut kenaikan upah. ${ }^{24}$ Selain di sektor Perkebunan, di sektor pertambangan minyak juga terjadi aksi pemogokan dengan alasan menuntut kenaikan upah. Hal ini terjadi di pertambangan minyak Sumatera Selatan dan Jambi, sekitar 23.800 buruhnya melakukan aksi mogok menuntut kenaikan upah selama dua bulan terhitung sejak tanggal 18 Juli $1950 .{ }^{25}$ Di sektor rokok, sejak tangga12 September 1950 telah terjadi pemogokan yang dilakukan oleh buruh-buruh BAT yang menuntut kenaikan upah. ${ }^{26}$ Di Tasikmalaya pada tahun yang sama, buruh-buruh pabrik kendaraan bermotor menuntut perbaikan upah dan meminta agar syarat-syarat kerja yang diatur dalam Peraturan Perusahaan ditinjau kembali. Tuntutan ini diikuti dengan aksi pemogokan, dan mereka baru menghentikan aksi mogoknya setelah tuntutannya di kabulkan perusahaan. ${ }^{27}$ Selanjutnya dengan alasan menuntut tambahan tunjangan kemahalan sebesar 20\% yang ditolak oleh

Justitia Vol. 27 No. 2 Oktober 2009 FH Unpar Bandung, hlm. 193-201

22 Buruh-buruh PT. SIN melakukan mogok kerja menuntut pemberian: kompensasi tambahan dan perbaikan kondisi pekerjaan kepada pihak manajemen perusahaan Suara Pembaharuan, 8 Mei 2000.

23 Meskipun baru terbentuk pada tahun 1947, Serikat Buruh Perkebunan Republik Indonesia pada tahun 1948 telah mengkoordinir pemogokan yang melibatkan 15.500 buruh dari pabrik karung dan goni dan 7 (tujuh) perusahaan, perkebunan di Delanggu menuntut kenaikan upah mulai dari tanggal 23 Juni sampai dengan 17 Juli 1948. Harian Berita Indonesia, 17 Juli 1948, hlm. 1

24 Pemogokan ini didukung oleh masyarakat sekitarnya dengan melakukan unjuk rasa serta oleh SOBSI dan BTI baik tingkat Pusat maupun tingkat Cabang Cilacap dan Sabang. Harian Indonesia, 2 Agustus 1950, hlm. 1.

25 Harian Indonesia, Ibid.

26 Harian Indonesia, 3 Oktober 1950, hlm. 1.

27 Harian Indonesia, 27 Oktober 1950, hlm. 3. 
pengusaha, buruh-buruh Pabrik Bir Heineken's pada tahun 1959 melakukan mogok kerja di bawah koor-dinasi Serikat Buruh Makan dan minum. ${ }^{28}$ Pada tahun-tahun terakhir ini juga terlihat besarnya jumlah angka pemogokan kerja mulai tahun 2003 sampai dengan tahun 2008, yaitu sebagai berikut: tahun 2003 sejumlah 248 pemogokan, tahun 2004 sebanyak 356, tahun 2005 sebanyak 27, tahun 2006 sebanyak 127, tahun 2007 se-banyak 275 dan tahun 2008 sebanyak 79 mogok kerja. ${ }^{29}$

Kedua, tuntutan pekerja terhadap pengusaha agar melaksanakan ketentuan-ketentuan hak-hak normatif pekerja yang ada dalam hukum perburuhan juga melatarbelakangi pemogokan di Indonesia. Tuntutan semacam ini sering disebut tuntutan kaum pekerja yang bersifat normatif. sedikitnya 800 pekerja PT. A.P. pada tahun 1996 yang berlokasi di Jakarta Timur melakukan mogok kerja. Mereka menuntut agar pengusaha melaksanakan ketentuan dalam perjanjian perburuhan yang menyatakan buruh yang perjanjian kerjanya telah diperpanjang dua kali berhak menjadi buruh tetap. ${ }^{30}$ Pada tahun yang sama sekitar 400 pekerja PT. PAC di Teluk Gong Jakarta Utara, melakukan mogok kerja menuntut pelaksanaan ketentuan upah minimum sebagaimana telah diatur dalam Keputusan Menteri Tenaga Kerja tentang ketentuan upah minimum Wilayah DKI-Jakarta. ${ }^{31}$ Sekitar 3.500 pekerja PT. WST di Jakarta Barat, melakukan mogok kerja karena upah mereka dibayarkan tidak sesuai dengan perjanjian kerja. ${ }^{32}$ Mogok kerja yang dilatar belakangi tuntutan pelaksanaan ketentuan upah minimum ini juga terjadi, pada PT. GT. yang berlokasi di Tuban, Jawa Timur. ${ }^{33}$

Ketiga, pemogokan-pemogokan yang di latarbelakangi alasan-alasan politik juga terjadi pada awal kemerdekaan Republik Indonesia. Bahkan pada saat menjelang Kemerdekaan Republik Indonesia telah terjadi pula pemogokan

\footnotetext{
28 Harian Umum, 17 Maret 1959, hlm. 2.

29 Laporan Dirjend Pembinaan dan Pengawasan Depnaker 2003-2008. http: //www. depnakertrans. org.id.

Harian Merdeka, 13 Agustus 1996, hlm. I.

Republika, 12 Agustus 1996, hlm. 1.

Merdeka, 22 Agustus 1996, hlm. 2.

33 Surya, 4 September 1996, hlm.1.
}

yang dilatarbelakangi alasan politik. ${ }^{34}$ Selanjutnya pada awal kemerdekaan telah terjadi pemogokan dan mogok kerja yang berlatarbelakang politik yang dilakukan oleh 50.000 pekerja swasta dan pegawai negeri pada tanggal 28 Desember 1950 di Makasar, menuntut agar Pemerintah Belanda mengembalikan Irian Barat kepada Indonesia; Keputusan Konferensi Meja Bundar dibatalkan; dan Uni Indonesia dibubarkan. ${ }^{35}$

Demikian pula pada tahun 1964, para pekerja dari 7 (tujuh) perusahaan perkebunan milik Amerika Serikat melakukan mogok kerja karena memprotes Amerika Serikat telah mengadakan perjanjian kerjasama dengan Ma-laysia serta protes terhadap tindakan agresi Amerika Serikat ke Vietnam. ${ }^{36}$ Keempat, pemogokan-pemogokan yang terjadi di Indonesia juga disebabkan adanya tuntutan hak-hak dasar (fundamental rights) kaum pekerja. Misalnya pemogokan-pemogokan yang berlatarbelakangi atau bertujuan untuk mendirikan serikat pekerja di perusahaan tempat mereka bekerja. Hal ini dapat dibuktikan dari beberapa contoh terjadinya pemogokan yang alasannya menuntut pembentukan Serikat pekerja di beberapa perusahaan di Indonesia. Misalnya pada tahun 1990, pekerja PT. PR, Tangerang melakukan pemogokan menuntut pembentukan Serikat pekerja di perusahaan tempat mereka bekerja. ${ }^{37}$ Pada tahun 1991, dengan alasan 6 orang pengurus Serikat Pekerja Tingkat Perusahaan diputuskan hubungan kerjanya oleh pihak manajemen perusahaan, ratusan pekerja PT. BTI Ungaran Jawa Tengah, melakukan aksi mogok menuntut agar ke enam orang pengurus serikat bpekerja tingkat Perusahaan tersebut dipekerjakan kembali. ${ }^{38}$ Demikian pula di Bekasi, pada tahun 1993, 1.000 pekerja PT. AMIG melakukan aksi

34 Sebelum Indonesia merdeka, tepatnya pada tahun 1920, PFB (Personeels Fabrieks Bond) mengkoordinir kaum buruh di pabrik-pabrik gula milik pengusaha Belanda untuk melakukan pemogokan dengan tujuan untuk menggulingkan Pemerintahan Hindia Belanda. Lihat: Iskandar Tedjasukmana, 1958, The Political Charter of The Indonesian Trade Union Movement, Itacha, New York: Cornell University Monograph Series, hlm. 12.

35 Harian Indonesia, 29 Desember 1950, hlm. 1.

36 Trompet Masyarakat, 3 September 1964, hlm.1.

37 Kompas, 2 Februari 1990, hlm. 2.

38 Kompas, 12 November 1991, hlm. 1. 
pemogokan menuntut agar di perusahaan tempat mereka bekerja dibentuk Serikat Pekerja. ${ }^{39}$ Sekitar 380 pekerja PT. OPC Tangerang di tahun 1994 mulai menghentikan aksi mogoknya dan mulai bekerja kembali setelah tuntutan pembentukan Serikat Pekerja di perusahaan tempat mereka bekerja dikabulkan oleh perusahaan. ${ }^{40}$

Kelima, mogok dirasakan oleh pekerja sebagai senjata dalam memperjuangkan tuntutannya. Berbagai kasus pemogokan yang terjadi di perusahaan-perusahaan menunjukkan bahwa hak mogok oleh pekerja dirasakan sebagai senjata untuk memperjuangkan tuntutan pekerja, karena dari kasus-kasus pemogokan yang terjadi di berbagai wilayah, para pengusaha baru mengabulkan tuntutan pekerja setelah mereka mengadakan pemogokan. Sebagai contoh di sini misalnya dapat dikemukakan pada tahun 1991 PT. PAI Tangerang akhirnya mengabulkan tuntutan kenaikan upah para pekerjanya setelah mereka mengadakan pemogokan selama dua hari. ${ }^{41}$ Demikian pula PT. IBP Tangerang mengabulkan tuntutan pembentukan serikat pekerja di perusahaannya setelah para pekerjanya mengadakan pemogokan pada tahun yang sama. ${ }^{42}$ Unjuk rasa ke Kantor Wilayah Departemen Tenaga Kerja Medan telah menggagalkan pemutusan hubungan kerja seorang pekerja. ${ }^{43}$

Jika dilihat dari dampak yang ditimbulkan, setidak-tidaknya mogok kerja dapat menyebabkan 6 masalah yaitu kerugian materiil bagi perusahaan, menghambat pertumbuhan ekonomi nasional, menimbulkan ketidakstabilan politik dan ekonomi, menghambat masuknya investasi, dan menghambat kegiatan ekspor dan menurunnya produktivitas perusahaan. Keenam dampak yang ditimbulkan oleh aksi pemogokan tersebut di atas dapat diuraikan sebagai berikut ini.

Pertama, mogok kerja dapat mengakibatkan kerugian materiil bagi perusahaan, karena mogok kerja secara langsung menjadi

\footnotetext{
Kompas, 18 Maret 1993, hlm. 2.

Kompas, 28 Maret 1994, hlm. 2.

Kompas, 5 Februari 1991, hlm. 3.

Bisnis Indonesia, 6 April 1991, hlm. 2.

Suara Pembaharuan, 19 Juni 1991, hlm. 2.
}

sebab hilangnya jam kerja untuk berproduksi. ${ }^{44}$ Di seluruh negara Eropa barat pada akhir tahun 1970-an telah terjadi pemogokan sebanyak 14.754 kali yang melibatkan 21 juta pekerja, mengakibatkan 54,6 juta jam kerja yang hilang. ${ }^{45}$ Selanjutnya pemogokan yang terjadi di Amerika Serikat pada tahun 1976 telah mengakibatkan 38 juta jam kerja yang hilang. ${ }^{46}$ Demikian pula di Jepang pada tahun 1976 tercatat 3,26 juta jam kerja telah hilang akibat pemogokan. ${ }^{47}$ Selanjutnya 270 pemogokan di Cina pada bulan Maret 1994 yang berlangsung selama 40 hari telah melibatkan 10.000 pekerja. Demikian pula sebelumnya selama 6 bulan pada tahun 1956-1957 telah terjadi 10.000 kali pemogokan. ${ }^{48}$ Pada tahun 1987-1988 di Cina juga telah terjadi 200 kali pemogokan. ${ }^{49}$ Selama periode tahun 2000 sampai dengan April 2005, Indonesia kehilangan jam kerja akibat mogok sebesar 8.000.381 jam. ${ }^{50}$

Kedua, hilangnya jam kerja akibat pemogokan sebagaimana telah diuraikan di atas, pada gilirannya secara mikro akan menurunkan hasil produksi dan secara makro merupakan salah satu faktor yang menghambat pertumbuhan ekonomi nasional. Antara tahun 1965 sampai dengan tahun 1980, rata-rata pertumbuhan ekonomi Indonesia adalah 7\%, selanjutnya antara tahun 1980 sampai dengan tahun 1990 terjadi penurunan pertumbuhan ekonomi ratarata adalah $5,5 \% .{ }^{51}$ Demikian pula pertumbuhan

44 Selama 5 tahun terakhir terhitung sejak tahun 2000 sampai dengan bulan April tahu 2005, jumlah jam kerja yang hilang akibat pemogokan tercatat 900.351 jam, melibatkan 800.352 buruh. Lihat: Laporan-laporan Tahunan Direktur Jenderal Binawas Departemen Tenaga Kerja Republik Indonesia dari tahun 2000 sampai dengan April 2005

45 Time, 2000, hlm. 2.

46 Gould, Op. Cit, hlm. 15-16.

47 Gould, Ibid. hlm.17.

48 Xiabo Lu and Elizabeth J. Perry, ed., DANWEl: The Changing Chinese Workplace in Historical and Comparative Perspective, NewYork, London: an East gate Book, hlm. 48-5

49 William M. Moore, "China Industrial Relations: Amid the Conflic Tradition and Reform," Labor Law Journal, hlm. 40, (December 1991, No. 12).

50 Data diolah dari Laporan Tahunan Perkembangan, kasus pemogokan dikeluarkan oleh Direktur Jenderal Pembinaan dan pengawasan tenaga kerja Departemen Tenaga Kerja 2000 s/d April 2005.

51 John Bresnan, 1993, Managing Indonesia: The Modern Political Economy, New York: Columbia University Press, hlm. 24 
GNP per kapita (Gross National Product) dari tahun 1965 sampai dengan tahun 1990 rata-rata adalah 4,5\%. ${ }^{52}$ Di Inggris kerugian materiil akibat mogok secara keseluruhan mencapai 6 milyar pound sterling, apabila dibandingkan dengan GNPnya, jumlah kerugian ini setara dengan 2\% dari GNP negara Inggris ${ }^{53}$

Ketiga, frekuensi pemogokan yang tinggi dan berskala besar dan dalam waktu yang lama dapat menimbulkan ketidakstabilan ekonomi dan politik. Frekuensi mogok kerja yang demikian adalah pada tahun-tahun menjelang krisis moneter 1997. Pada tahun 1994 sampai dengan tahun 1996, jumlah pemogokan mencapai 2.689 kali, dan pada tahun 1997 sendiri jumlah pemogokan mencapai 1.203 kali. $^{54}$ Krisis moneter 1997 yang berkepanjangan hingga saat ini juga telah mengakibatkan krisis politik yang belum menunjukan adanya pemulihan ekonomi hingga saat ini.

Keempat ketidakstabilan politik dan ekonomi yang diakibatkan oleh frekuensi mogok yang tinggi dan berskala besar serta dalam waktu yang lama pada gilirannya dapat mengganggu iklim investasi. Dalam masa orde baru besarnya investasi selama PELITA-IV adalah Rp. 240 trilyun, selanjutnya selama PELITA-VI besarnya investasi mencapai Rp. 660 trilyun. ${ }^{55}$ Krisis moneter yang diikuti dengan krisis politik ini telah menghambat masuknya penanaman modal asing ke Indonesia. bahkan penanam modal asing yang sudah menanamkan modal di Indonesia mengancam akan memindahkan modalnya ke negara lain. ${ }^{56}$

52 Ibid.

53 Menurut Laporan Tahunan dari National Coal Board, kerugian materiil akibat mogok sebesar 1,750 juta poundsterling; Electricity Board menanggung kerugian sebesar 2.020 juta poundsterling; British Rail menanggung kerugian sebesar 250 juta poundsterling; dan British Steel menanggung kerugian sel 1 SO juta pound sterling. Lihat: Tony Weir, "A Strike Against the Law?," Mark Law Review, 46, Summer 1986, No. 1: hlm. 133

54 Lihat: Laporan Tahunan tentang Perkembangan Kasus pemogokan yang dikeluarkan oleh Direktur Jenderal Pembinaan dan Pengawasan Departemen tenaga kerja Republik Indonesia dari tahun 1994 s/d 1997.

55 Sjahrir, 1993, Ekonomi: Enak Dibaca dan Perlu, Jakarta: PT. Pustaka Utama Graffiti, hlm. 225.

56 PT. SIN akan hengkang dari Indonesia, jika buruh-buruh PT. SIN tetap melakukan mogok. Kompas, 21 Mei 2000, hlm. 1.
Kelima, kegiatan ekspor-impor dapat terganggu oleh aksi pemogokan. Pada tahun 1950 di Medan, sekitar 3.000 pekerja pelabuhan Belawan melakukan aksi mogok kerja selama sepekan. Pemogokan dimaksudkan untuk menuntut kenaikan upah ini telah mengakibatkan kegiatan ekspor-impor terhenti sehingga menimbulkan kenaikan harga beras. ${ }^{57}$ Perkembangan ekspor tekstil misalnya dari tahun1992 sampai dengan tahun 1994 mengalami kenaikan dan penurunan pada tahun 1992 ekspor tekstil Indonesia adalah US\$ 5.957 milyar, selanjutnya pada tahun 1993 naik menjadi US\$ 6.064 miliar akhirnya pada tahun 1994 ekspor tekstil Indonesia menurun menjadi US\$ 4.03 miliar. ${ }^{58} \mathrm{Ke}$ enam, dampak mogok kerja juga akan mengurangi produktivitas perusahaan, apalagi pemogokan kerja yang memakan waktu lama akibat lamanya penyelesaian perselisihanm hubungan induystrial antara pekerja dengan pengusaha.

Meskipun dilihat dari dampak yang ditimbulkan suatu mogok kerja dapat menjadi salah satu faktor yang dapat mengganggu pertumbuhan ekonomi suatu negara, namun terjadinya mogok kerja tidak mudah untuk dihapuskan oleh pemerintah melalui berbagai peraturan perundangan yang melarang atau mencegah pemogokan. Dilihat dari sejarah mengenai pengaturan mogok kerja, di berbagai negara telah mencoba untuk mencegah terjadinya mogok melalui ketentuan yang mencantumkan ancaman sanksi pidana maupun sanksi perdata terhadap pelaku pemogokan ataupun terhadap pengurus serikat pekerja yang menggerakkannya. ${ }^{59}$

Melalui ketentuan-ketentuan yang memuat ancaman sanksi pidana pemerintah melarang atau mencegah terjadinya suatu pemogokan yang dilakiukan secara ilegal seperti diatur dalam Keputusan Menteri Tenaga Kerja Dan Transmigrasi RI No. 232/MEN/2003 Tentang Akibat Hukum Mogok Kerja Yang Tidak Sah.

Harian Indonesia, 11 Oktober 1950, hlm. I .

58 Syahrir, op.cit, hlm. 230

59 Dalam hal ini mogok dikonsepkan sebagai persekongkolan jahat yang dilakukan oleh kaum buruh untuk menghambat kemajuan perusahaan dan kemajuan ekonomi dan perdagangan. Doug E. Ray, et.al., 1999, Understanding labor Law, New York: Matthew Bender \& Company, Inc., hlm.10. 
Pemerintah Inggris melarang pemogokan melalui beberapa ketentuan misalnya Combination Act 1825 sebagai pengganti Criminal conspiracy Statute. Amerika Serikat melarang pemogokan melalui Sherman Act 1980 yang mempertegas Section 7. Common Law Doctrine of Conspiracy Selanjutnya Jerman melarang mogok kerja melalui Anti Socialist Act 1878. Belanda melarang pemogokan melalui Pasal 414 dan 416 WvS Demikian pula pemerintah Cina melarang mogok melalui Pasal 224 provesional Penal Code 1920. Pemerintah Jepang juga pernah mengancam pemogokan dengan sanksi pidana. ${ }^{60}$

Melalui Pasal 161 bis dan Pasa1 335 ayat (3) KUH Pidana, pemogokan di Indonesia diancam dengan sanksi pidana. Meskipun kedua ketentuan pidana tersebut di atas telah dicabut, namun dengan diundangkannya Undang-undang No: 13 Tahun 2003 Tentang Ketenagakerjaan, pekerja-pekerja yang melakukan mogok ilegal diancam sanksi pidana(pasal 187 UU No. 13 Tahun 2003 Tentang Ketenagakerjaan).

Berdasarkan ketentuan perdata, mogok dikonsepkan sebagai tindakan perbuatan melanggar hukum (onrechtamatige daad) atau cidera janji (wanprestatie) terhadap perjanjian kerja, yang menimbulkan tuntutan ganti rugi dari pengusaha terhadap pekerja yang melakukan mogok kerja. Di Perancis setelah tahun 1792, serikat pekerja yang menggerakan pemogokan dibebani tanggung jawab perdata, karena mereka dianggap melakukan perbuatan melanggar hukum atau melakukan cedera janji. ${ }^{61}$ Pembebanan tanggung jawab perdata terhadap serikat pekerja yang menggerakan pemogokan ini juga terjadi di Belanda dan Jerman. Bahkan melalui ketentuan yang mengatur hubungan kerja, pekerja yang melakukan mogok kerja dianggap mengakhiri hubungan kerja secara permanen (pemutusan hubungan kerja) atau mengakhiri hubungan kerja untuk sementara waktu (skorsing). Pekerja dianggap memutuskan hubungan kerja jika melakukan mogok ker-

60 Sioban M. Healy, "Labor Relations in Japan, The United States, and W Britain: Culture and Conflict," Connecticut Journal of International Law 4, September 1988, No. 3, hlm. 44-45.

61 P. Zonderland, 1974, Recht en Pticht by Staking en Tegenstaking, Deventer: Kluwer, hlm.165-157. ja ini, juga diterapkan di Belanda sebelum serikat pekerja yang menggerakan pemogokan dibebani tanggung jawab perdata sebagaimana telah teruraikan di atas. ${ }^{62}$

Negara-negara yang awal mulanya mengatur mogok dalam hukum pidana maupun perdata, dalam perkembangannya mengakui mogok sebagai hak atau sebagai kebebasan. Di Inggris, misalnya: berdasarkan: Trade Dispute Act 1906 yang memuat prinsip Golden Formula, serikat pekerja di Inggris memiliki hak kekebalan (immunity rights). Serikat pekerja dapat dituntut pertanggunganjawab pidana mau pun perdata pada saat menggerakan pemogokan sebagai akibat atau kelanjutan dari suatu perselisihan perubahan. ${ }^{63}$ Negara-negara Eropa yang tergabung dalam masyarakat Ekonomi Eropa yang telah meratifikasi European Social Charter; mengakui mogok sebagai hak. Hal ini sejalan dengan pandangan neoliberalisme, bahwa mogok adalah hak kaum pekerja yang memiliki landasan yuridis, sehingga setiap kebijaksanaan pemerintah yang hendak menghapuskan atau melarang hak mogok akan mendapatkan kecaman dari dunia internasional. ILO (International Labor Organization ) mengakui mogok sebagai hak fundametal kaum pekerja yang tidak dapat dipisahkan (inherent) dari hak berserikat dan berunding kolektif (freedom of association). Selanjutnya pada era globalisasi yang menekankan perdagangan bebas, negara-negara maju sama sekali tidak memberikan toleransi kepada negara-negara berkembang yang menentukan upah murah dan pelaksanaan peraturan perundang-undangan perburuhan yang lunak sebagai keunggulan komparatif. Menurut negara-negara maju, tindakan negara-negara berkembang yang menggunakan upah murah dan pelaksanaan peraturan perburuhan yang lunak dianggap melakukan social dumping. ${ }^{64} \mathrm{Upa-}$

62 Ibid., hlm. 167

63 A.T.J.M. Jacobs, 1986, Recht op Collectief Onderhandelen: in Rechtsvergelijkend en Europeen Perspectief, Alpehen aan den Rijn: Samson H.D Tjeenk Willink, hlm. 150

64 "Social Dumping" digambarkan sebagai suatu proses dimana mereka memperlakukan para buruh secara tidak wajar untuk menurunkan biaya produk lihat: Erika de Wet, "Labor Standard in Globalization Economy: The inclusion Social Clause in the GATT/WTO", Human Rights Quaterly, 17, (1999), hlm. 148. 
ya pemerintah dalam pencegahan; maupun perundangan mogok melalui ketentuan-ketentuan yang bersifat pidana maupun perdata, menunjukan bahwa pemogokan tidak dapat dihindarkan. Lebih-lebih mogok dalam perkembangan terakhir telah diakui diakui sebagai hak.

\section{Banyaknya Jumlah Perselisihan Hubungan In- dustrial Antara Pengusaha Dan Pekerja}

Hubungan industrial yang bersifat kapitalistik berdampak pada timbulnya perselisihan hubungan industrial antara pekerja dengan pengusaha. Perselisihan pekerja dengan pengusaha pada dasarnya dapat terjadi dengan didahului atau tanpa didahului suatu pelanggaran hukum. Jika suatu perselisihan perburuhan diawali dengan suatu tindakan pelanggaran hukum (perselisihan hak), perselisihan hubungan industrial demikian itu pada umumnya disebabkan oleh beberapa faktor. ${ }^{65}$ Pertama, sebagai akibat terjadinya perbedaan faham tentang pelaksanaan hukum ketenagakerjaan. Hal ini tercermin dalam tindakan pengusaha atau pekerja yang melanggar suatu ketentuan hukum. Misalnya pengusaha membayar upah pekerja-pekerjanya di bawah ketentuan hukum yang mengatur upah minimum; atau pengusaha tidak memberikan cuti tahunan sebagaimana diatur dalam Undang-Undang No. 13 tahun 2003 tentang Ketenagakerjaan. Pelanggaran hak pekerja oleh pengusaha di sini merupakan faktor penyebab terjadinya perselisihan hubungan industrial. Kedua, perselisihan hubungan Industrial yang dialami dengan pelanggaran hukum ini, juga dapat disebabkan oleh terjadinya perbedaan perlakuan yang tercermin dalam tindakan pengusaha yang bersifat diskriminatif. Misalnya, meskipun jabatan, pendidikan, masa kerja, prestasi kerja, dan produktivitas kerjanya sama, namun karena " $\mathrm{A}$ " adalah pria, pengusaha membayarkan upah kepada "A" lebih besar dari "B" yang senyatanya adalah perempuan. Pembedaan upah antara "A" dan "B" di sini bersifat diskriminatif karena didasarkan pada perbedaan gender. Perlakuan diskriminatif ini dapat diperluas pada ruang lingkupnya hingga

65 Charles D. Drake, 1981, Labor Law, 3th. Ed. London: Sweet \& Maxwell Ltd., hlm. 240. mencakup diskriminasi berdasarkan suku, ras, atau agama yang berbeda. ${ }^{66}$

Perselisihan hubungan Industrial yang tanpa didahului suatu pelanggaran hukum (perselisihan kepentingan), pada umumnya juga disebabkan oleh beberapa faktor. ${ }^{67}$ Pertama, adanya perbedaan pendapat dalam menafsirkan hukum perburuhan. Misalnya berdasarkan ketentuan hukum tertentu, menurut pengusaha, pekerja tidak berhak melaksanakan cuti sebelum melahirkan dan setelah la melahirkan anak secara prematur. Di lain pihak pekerja atau serikat pekerja menafsirkan bahwa ketentuan hukum tersebut menjamin cuti sebelum dan setelah melahirkan tetap merupakan hak pekerja wanita yang melahirkan anak secara prematur. Kedua, perselisihan hubungan industrial yang tidak diawali oleh suatu pelanggaran, juga dapat disebabkan oleh terjadinya ketidaksepahaman tentang perubahan ketentuan hukum yang mengatur upah atau syarat-syarat kerja lainnya. Perselisihan perburuhan semacam ini tercermin dalam perselisihan perburuhan yang berkaitan dengan upaya perbaikan syarat-syarat kerja yang dilakukan oleh serikat pekerja atau perubahan isi peraturan perusahaan yang dilakukan oleh pengusaha. Misalnya serikat pekerja menuntut kenaikan upah, uang transport, atau uang ma-kan, sebesar $75 \%$ dari upah.

Perselisihan hubungan industrial yang disebabkan oleh ketidaksepahaman tentang perbedaan pelaksanaan hukum perburuhan, pembedaan perlakuan, dan ketidaksepahaman dalam menafsirkan hukum perburuhan sebagaimana telah diuraikan di atas, disebut perselisihan hak (conflict of rights). ${ }^{68}$ Sedangkan

66 Lihat tentang masalah gender dalam pekerjaan ini pada Catharina Dewi Wulansari, "Perbedaan Pengaturan tentang Pekerja Perempuan dan Laki-laki Di Indonesia Ditinjau dari Teori Ketidaksamaan Seksual”, Jurnal Hukum Pro Justitia Tahun XIII No. 1 Januari 2005, hlm. 818.

67 Charles D. Drake, op.cit., hlm. 240.

68 T. Hanami dan R. Blanpain, Introducton' Remarks and Comparative Overview, T. Hanami, ed., dalam Industrial Convlict Resolution in Market Economies: A Study of Canada, Great Britain, and Sweden (Deventer/ Netherlands : Kluwer Law and Taxation Publishers, 1987), $\mathrm{hlm}$. 6. Lihat: Xavier B1anc-Jouvan, The Setlfemenl of Labor Disputes in France, Benjamin Aaron, ed., dalam Labor Courts and Grievance Settlement in Western Europe, Berkeley Los Angeles: University of California Press, 1971, 8-9. Lihat juga: Dennis R.1 Jolan, 
perselisihan perburuhan yang disebabkan oleh ketidaksepahaman tentang perubahan syaratsyarat kerja dikategorikan sebagai perselisihan kepentingan (conflict of interest) ${ }^{69}$. Dalam perselisihan hak, hukumnya dilanggar, tidak dilaksanakan, atau ditafsirkan secara berbeda. Sedangkan dalam perselisihan kepentingan, hukumnya belum ada karena dalam perselisihan kepentingan ini, para pihak memperselisihkan hukum yang akan dibentuk.

Kedua jenis perselisihan perburuhan tersebut di atas menentukan sifat dari bentuk/ jenis pemogokan apakah pemogokan tersebut masuk dalam kategori pemogokan yang bersifat normatif atau di luar normatif. Jika pemogokan tersebut terjadi karena adanya perselisihan kepentingan yang berkaitan dengan ketidaksepahaman tentang perubahan ketentuan yang mengatur syarat-syarat kerja, maka pemogokan tersebut bersifat di luar normatif. Hal ini tercermin dalam kasus pemogokan yang menuntut kenaikan upah atau perbaikan kesejahteraan, atau perbaikan syarat-syarat kerja serta kondisi kerja lainnya.

Selanjutnya jika pemogokan tersebut di sebabkan oleh perselisihan hak atau hukum yang antara lain berkaitan dengan tidak adanya kesepahaman tentang perbedaan pelaksanaan hukum perburuhan atau akibat pembedaan perlakuan terhadap buruh, maka pemogokan tersebut bersifat normatif. Hal ini tercermin dalam kasus pemogokan yang disebabkan oleh tuntutan buruh agar pengusaha melaksanakan ketentuan upah minimum, atau ketentuan hukum lainnya yang menjadi kewajiban pengusaha.

Terjadinya perselisihan hubungan Industrial yang diikuti oleh pemogokan ini merupakan fenomena yang tidak mudah untuk dihindari atau dicegah. Hal ini antara lain disebabkan oleh beberapa hal. Pertama belum terlaksananya hubungan kemitraan di tempat kerja. Dilihat dari segi pengusaha, hal ini merupakan akibat dari sikap pengusaha yang memandang

"Regulation of Industrial Disputes in Australia, New Zealand, and The United States", Wirittier Law Review II (Winter 1990, No. 4), hlm. 761

69 Dennis R.l Jolan, loc.cit, hlm. 761 kaum pekerja hanya sebagai faktor komplementer produksi serta hanya berorientasi mencari keuntungan semata. Sedangkan dari segi pekerjanya, belum berjalannya hubungan kemitraan di tempat kerja ini disebabkan oleh kurangnya rasa memiliki (sense of belonging) kaum pekerja terhadap perusahaan dimana mereka bekerja. Pekerja cenderung untuk mendapatkan upah yang besar tanpa harus bekerja keras. Kedua, kegagalan perundingan yang dilaksanakan oleh para pihak dalam menyelesaikan perselisihan hubungan industrial yang terjadi sebagai akibat ketiadaan hubungan komunikasi yang baik dan efektif. Hal ini antara lain disebabkan oleh belum adanya lembaga-lembaga yang berfungsi sebagai forum komunikasi, dimana partisipasi kaum pekerja dapat dilaksanakan. Ketiga lamanya proses penyelesaian perselisahan perburuhan yang tercermin dalam mekanisme penyelesaian perselisihan hubungan industrial sebagaimana diatur dalam UU No. 2 Tahun 2004 tentang Penyelesian Perselisihan Hubungan Industrial, yang proseduralnya masih paanajang. Misalnya perselisihan hak dimulai perundingan di lembaga bipartit antara pengusaha dan pekerja, apabila belum adaa kesepakatan diajukan ke mediasi di depnakertran setempat, apabila masih belum ada kesepakaatan diajukan ke Pengadilan Hubungan industrial, dan terakhir diajukan kasasi apabila salah satu pihak mengajukan upaya hukum atas putusan Pengadilan Hubungan Industrial (Pasal 110 UU No. 2 Tahun 2004 Tentang PPHI). Berangkat dari sumber terjadinya perselisihan hubungan industrial yang beresiko munculnya terjadinya pemogokan, serta faktor-faktor pendorong terjadinya pemogokan tersebut di atas, maka untuk meng-atasi masalah mogok, pemerintah memiliki posisi sentral dalam menciptakan situasi yang kondusif bagi peningkatan hubungan kerjasama yang baik antara pengusaha dan pekerja-pekerjanya, tanpa harus melarang hak mogok kaum pekerja. ${ }^{70}$

70 Jika pemerintah memiliki posisi sentral, bagaimanakah posisi pekerja (buruh). Lihat dan baca C. Djiman Samosir, "Posisi Buruh dan Pengusaha dalam Menghadapi Milenium III", Majalah Hukum Pro Justitia Tahun XIX No. 1 Januari 2001 FH Unpar Bandung, hlm. 21-30 
Selanjutnya untuk mendorong tercapainya maksud tersebut di atas, perlu adanya tindakan konkrit dari para pelaku dalam proses produksi. Pertama, setiap keluh kesah ${ }^{71}$ yang baru akan muncul atau sudah sempat muncul ke permukaan, harus mendapatkan penanganan yang tepat dan cepat agar tidak berkembang menjadi perselisihan hubungan industrial yang mengarah pada digunakannya hak mogok. Oleh karena itu mekanisme penyelesaian keluh kesah (grievance procedure) merupakan suatu hal yang penting di setiap perusahaan. Kedua, hubungan kemitraan harus diterapkan dalam kehidupan sehari-hari, bukan hanya dijadikan slogan. Untuk itu perlu adanya institusi-institusi yang berfungsi sebagai media bagi kaum pekerja dan pengusaha dalam mengembangkan hubungan kemitraan. Ketiga, jika terjadi perselisihan hubungan industrial yang tidak dapat dicegah, lebih-lebih perselisihan hubungan industrial yang diikuti suatu tindakan pemogokan, maka diperlukan mekanisme penyelesaian perselisihan hubungan industrial yang dapat menjaga hubungan baik antara para pihak yang berselisih pada masa setelah terjadinya perselisihan.

Perselisihan industrial di PT South Pacific antara pengusaha atau pihak menajemen dengan pekerja seringkali terjadi, dikarenakan semua pekerja yang tidak menjabat secara struktural adalah menjadi anggota serikat pekerja PPMI PT South Pacific dan memiliki kesadaran mengenai hak dan kewajiban pekerja cukup tinggi. Sementara pihak pengusaha kurang memperhatikan kesejahtaraan pekerja yang sudah menjadi hak normatif pekerja. Apalagi kebijakan organisasi serikat pekerja PPMI di Kabupaten Purwakarta untuk meningkatkan perlindungan hukum pada pekerja yang berselisih dengan pekerja melalui jalur hukum secara konstitusional.

71 Keluh kesah (grievances) dapat digambarkan sebagai situasi dimana buruh atau serikat buruh mempertanyakan hal-hal yang berkaitan dengan penafsiran hukum, atau penerapan perjanjian kerja, peraturan perusahaan, atau perjanjian perburuhan; atau pertanyaanpertanyaan yang berkaitan dengan perubahan syaratsyarat kerja yang tercantum dalam perjanjian kerja, peraturan perusahaan, atau perjanjian perburuhan. Drake, Ibid., hlm. 23.
Untuk mencegah secara preventif terjadinya perselisihan industrial, pihak pengusaha PT South Pacific telah melakukan beberapa upaya sebagai berikut. Pertama, mengadakan pertemuan rutin sebulan sekali antara pihak pengusaha dengan pengurus serikat pekerja, untuk membahas masukan atau usulan dari para pekerja atau untuk sosialisasi program produksi maupun program kerja serikat pekerja; kedua, mengefektifkan lembaga bipartit di Perusahaan PT South Pacific dalam menyelesaikan perselisihan industrial yang diselesaikan secara musyawarah untuk mufakat; dan ketiga, mengikutsertakan pengurus serikat pekerja dalam pembuatan perjanjian kerja bersama, dan menampung usulan serikat pekerja dalam pembuatan kebijakan perusahaan yang menyangkut kepentingan pekerja.

Namun, formula ini tidaklah mengatur lebih lebih terperinci menyangkut hak dan tingkat kewenangan bagi pekerja dalam domain kebijakan perusahaan. Formula-formula semacam ini lebih bersifat akomodasi terhadap aspirasi yang pada tingkat kebijakan dan keputusannya tidak selalu melibatkan unsur-unsur pekerja.

Tidak hanya secara yuridis, tidak harmonisnya hubungan industrial ini, dalam berbagai observasi terhadap perkembangan hubungan industrial juga tampak hal-hal sebagaimana berikut. Pertama, pola-pola kapitalistik telah mendorong lahirnya keserakahan yang tidak terbatas sehingga seringkali menimbulkan tindakan-tindakan eksploitatif yang berlebihan terhadap pekerja. Tindakan eksploitatif bisa berupa pengingkaran terhadap hak-hak normatif pekerja seperti kebebasan berserikat. Kedua, dalam beberapa kasus, eksploitasi yang berlebihan ternyata tidak bisa memacu tingkat produktifitas yang tinggi karena tiadanya keseimbangan antara reward and punishment terhadap kinerja para pekerja. Ketiga, biasanya, pola eksploitasi yang dilakukan oleh perusahaan (pengusaha) dengan melakukan sterilisasi terhadap lembaga perserikatan pekerja. Modusnya, bisa berbentuk monolitik dengan hanya mengakui satu lembaga serikat pekerja, atau bisa juga dengan menempatkan orang-orang 
tertentu sebagai pengurus lembaga serikat pekerja sehingga bisa terkontrol dengan pasti untuk menjaga kepentingan perusahaan.

\section{Penutup \\ Simpulan}

Berdasarkan apa yang diuraikan di atas maka diperoleh kesimpulan sebagai berikut. Hubungan industrial antara pengusaha dengan serikat pekerja yang bersifat kapitalistik tidak dapat mewujudkan hubungan industrial harmonis. Desain konstruksi tatanan kapitalistik membentuk sistem eksploitasi dimana keberadaan pekerja lebih dipandang sebagai elemen pelengkap produksi untuk menunjang produktifitas yang tinggi. Desain ini, menempatkan fokus muara produksi semata-mata pada tujuan peningkatan profit yang berlipat ganda. Pada saat yang sama, upaya pekerja untuk mendapatkan hak-haknya yang dijamin secara yuridis, dipandang sebagai penghalang untuk tujuan mendapatkan keuntungan yang berlipat ganda itu. Oleh karena itu, posisi pekerja dan pengusaha berada pada posisi yang sangat berjarak secara diametral. Keduanya tidak menyatu dalam kesatuan sistem produksi yang saling bergantung antara satu dengan yang lain. Akibat Konstruksi tersebut di atas hubungan Industrial yang bersifat kapitalistik berdampak pada tingginya angka mogok kerja, manfaat mogok kerja sebenarnya adalah semu karena yang tercipta adalah keadilan prosedural, dan tidak pernah terjadi kesejahteraan substansial maupun keadilan substansial. Hubungan Industrial yang bersifat kapitalistik juga berakibat banyaknya perselisihan hubungan industrial antara pengusaha dengan pekerja. Untuk menghindarinya diperlukan lembaga kerjasama bipartit di perusahaan dan hubungan kemitaraan antara pengusaha dan pekerja.

\section{Saran}

Beberapa saran yang dapat diberikan sebagai pemecahan masalah tersebut di atas adalah sebagai berikut. Pertama, dalam rangka mewujudkan hubungan industrial harmonis diperlukan perubahan mindset pengusaha, pekerja dan pemerintah. Pengusaha harus me- rubah mindsetnya dari pekerja sebagai faktor produksi menjadi pekerja sebagai mitra dalam memenangkan persaingan usaha. Sebaliknya mindset pekerja juga harus berubah dari mindset pekerja yang berorientasi pada tuntutan kesejahteraan pekerja, berubah mindsetnya menjadi mitra pengusaha dalam kelanggengan perusahaan. Pemerintah juga harus merubah mindsetnya juga, dari fungsi negara sebagai regulator saja, berubah mindset menjadi fungsi negara yang mewujudkan kesejahteraan bersama.

Kedua, UU No. 21 Tahun 2000 Tentang Serikat Pekerja/Serikat Buruh perlu dilakukan penyempunaan, dengan lebih menitikberatkan melakukan perubahan pada paradigma hubungan industrial konflik antara pengusaha dengan pekerja, berubah menjadi hubungan industrial kemitraan antara pengusaha dengan pekerja.

\section{Daftar Pustaka}

Al-Zailiy, Wahjah. al-Wasid fi Ushlulfiqhi al-Islami. Bairut: Darul Kitab. 1397-1398 H/ 1977-1978 M;

Brecher, Jeremy. 1997. Strike. Cambridge: South End Press Classics;

Bresnan, John. 1993. Managing Indonesia: The Modern Political Economy. New York: Columbia University Press;

Drake, Charles D. 1981. Labor Law. 3th. Ed. London: Sweet \& Maxwell Ltd;

Gould, William B. "Labor Law in Japan and the United States: A Comparative Perspective". Industrial Relations Law Journal. Vol. 6 No. 1 1984;

Hanami, T. ed. 1987. Industrial Convlict Resolution in Market Economies: A Study of Canada, Great Britain, and Sweden. Deventer/Netherlands: Kluwer Law and Taxation Publishers;

Healy, Sioban M. "Labor Relations in Japan. The United States, and W Britain: Culture and Conflict". Connecticut Journal of International Law Vol. 4 No. 3 September 1988;

Jacobs, ATJM. 1986. Recht op Collectief Onderhandelen: in Rechtsvergelijkend en Europeen Perspectief, Alpehen aan den Rijn: Samson H.D Tjeenk Willink; 
Jolan, Dennis R1. "Regulation of Industrial Disputes in Australia, New Zealand, and The United States". Wirittier Law Review II. Winter, No. 4 1990;

Jouvan, Xavier B1anc. 1971. The Setlfemenl of Labor Disputes in France, Benjamin Aaron, ed. dalam Labor Courts and Grievance Settlement in Western Europe. Berkeley Los Angeles: University of California Press;

Laporan Dirjend Pembinaan dan Pengawasan Depnaker 2003-2008. http://www.depnakertrans. org.id;

Lu, Xiaobo and Elizabeth J. Perry, 1997, DANW'El: The Changing Chinese Workplace in Historical and Comparative Perspective, New York and London: An East Idle Book;

Milles, Mattew B. and A. Michael Huberma. 1992. Analisis Data Kualitatif. Jakarta: UI Press;

Moore, William M. "China Industrial Relations: Amid the Conflic Tradition and Reform". Labor Law Journal. No. 12. December 1991;

Muhadjir, Noeng. 2002. Metodologi Penelitian Kualitatif. Yogyakarta: Penerbit Rake Sarasin;

Nasution, S. 1996. Metode Penelitian Naturalistik Kualitatif. Bandung: Tarsito;

P. Zonderland. 1974. Recht en Pticht by Staking en Tegenstaking, Deventer: Kluwer;

Rahardjo, Satjipto. "Cara Bangsa Berhukum", Kompas. Senin 8 November 1993;

Ray, Doug E. et.al. 1999. Understanding labor Law. New York: Matthew Bender \& Company, Inc;

Salim, Agus. 2001. Teori dan Paradigma Penelitian Sosial (dari Denzin Guba dan Penerapannya). Yogyakarta: Tiara Wacana;

Samosir, C. Djiman. "Posisi Buruh dan Pengusaha dalam Menghadapi Milenium III". Majalah Hukum Pro Justitia. Tahun 19 No. 1. Januari 2001. Bandung: FH Unpar;

Sjahrir. 1993. Ekonomi: Enak Dibaca dan Perlu. Jakarta: PT. Pustaka Utama Graffiti;
Strauss, A. and J Corbin, Busir. 1990. Qualitative Research; Grounded Theory Procedure and Techniques. London: Sage Publication;

Suhardin, Yohanes. "Eksistensi Outsourcing dan Kerja Kontrak dari Perspektif Hak Asasi Manusia". Jurnal Hukum Pro Justitia Vol. 27 No. 2 Oktober 2009 FH Unpar: Bandung;

Sukapto, Paulus. “Penerapan Model Spencer \& Spencer dalam Penempatan Karyawan Secara Profesional". Jurnal Hukum Pro Justitia. Tahun 20 No. 1 Januari 2003. FH Unpar: Bandung;

Suteki.2008."Rekonstruksi HMN Atas Sumber Daya Air (Studi Kasus Privatisasi Air"), Disertasi, PDIH UNDIP Semarang;

Sutopo, HB. 1990. Metodologi Penelitian Kualitatif Bagian II. Surakarta: Universitas Negeri Sebelas Maret Press;

Tedjasukmana, Iskandar. 1958. The Political Charter of The Indonesian Trade Union Movement, Itacha. New York: Cornell University Monograph Series;

Weir, Tony. "A Strike Against the Law?". Mark Law Review. 46. Summer 1986. No. 1.

Wet, Erika de. "Labor Standard in Globalization Economy: The inclusion Social Clause in the GATT/WTO". Human Rights Quaterly, 17, (1999);

Wulansari, Catharina Dewi. "Dimensi Baru Peran Pemerintah dalam Mengatasi Masalah Ketenagakerjaan Melalui Pem-bangunan Hukum Di Indonesia". Jurnal Hukum Pro Justitia. Vol. 24 No. 3 Juli 2006. Bandung: FH Unpar;

“Perbedaan Pengaturan tentang Pekerja Perempuan dan Laki-laki Di Indonesia Ditinjau dari Teori Ketidaksamaan Seksual". Jurnal Hukum Pro Justitia. Tahun 13 No. 1. Januari 2005. Bandung: FH Unpar;

Xiabo Lu and Elizabeth J. Perry, ed., DANWEl: The Changing Chinese Workplace in Historical and Comparative Perspective, New York, London: an East gate Book. 